\title{
Subjective Well-Being, Politics and Political Economy
}

\author{
BRUNO S. FREY ${ }^{\mathrm{a}}$
}

Keywords: Happiness, well-being, economic policy, manipulation, political economy. JEL-Classification: A10, D70, H11, I31.

\section{Happiness: Research and Policy}

Over the last few years, economists have engaged in the study of subjective wellbeing. They have followed the lead of philosophers who, from the very beginning, have pondered about that subject (e.g. McMaHon, 2006); followed by psychologists who have developed methods for measuring it (e.g. Kahneman, Diener and Schwarz, 1999; Gilbert, 2006; Haybron, 2008). Economists are latecomers because they uncritically stuck to the idea proposed a long time ago by RoBBins (1932) and Hicks and Allen (1934), that utility cannot be measured. This has remained a dogma, as can be seen by consulting any standard textbook in microeconomics. However, things have changed somewhat; it has been demonstrated that utility can be approximated by well-being measures. As a result, happiness economics has become one of the most thriving and "hot" subjects in our discipline ${ }^{1}$. One may even argue that it is "revolutionary" (FrEY, 2008) as it opens new dimensions to research, produces new insights, and allows for new policies benefiting individuals and society. Happiness research is one of the few areas in the social sciences which are truly interdisciplinary; in particular psychologists and economists are working closely together. Moreover, it is a discipline in which European scholars are as prominent as North Americans.

a Department of Economics, University of Zurich, Wilfriedstrasse 6, ZH-8032 Zurich, Switzerland. E-mail: bruno.frey@econ.uzh.ch. I am grateful for helpful remarks to Reto Cueni, Jana Gallus, Margit Osterloh and Lasse Steiner.

1 For a history see e.g. Bruni (2006). Forerunners are VAn PraAg and Kapteyn (1973), EasterLiN (1974), followed by LAYARD (1980) and VeEnHoven (1989). Recent surveys are presented e.g. by Lane (2000), Layard (2005), Di Tella and MacCulloch (2006), Frey and Stutzer (2002a,b, 2004, 2005), Frey (2008), Frey and Frey Marti (2011), Dolan, Peasgood and White (2008). Collections of essays are e.g. Easterlin (2002, 2010), Eid and LarSen (2008), Dutt and RadCliff (2009). Happiness policy is discussed e.g. in BoK (2010). A critical view is presented in BARrotta (2008). 
Knowledgeable scholars now agree that it is possible to proxy utility by happiness measures (e.g. Kahneman and Krueger, 2006). The various measures are certainly not ideal but compare well with other measures commonly used in economics such as Gross National Product, the rate of inflation or the rate of unemployment. In line with the literature, I use the terms "subjective well-being", "happiness", and "life satisfaction" interchangeably.

This paper does not intend to present the results of happiness research. These are based on sophisticated econometric methods which rely on large numbers of individual data, often in panel form, and take into account estimation problems such as endogeneity issues ${ }^{2}$. It must suffice to point out some highlights, in particular results that stand in contrast to the economics as presented in our textbooks. According to standard economics, work is a burden while leisure provides positive utility. It follows that a person without work but having the same income as with work should be in paradise. In contrast, happiness research convincingly shows that people losing and not having work are much less happy than people with a job even when income is kept constant. There are several results of happiness research that emphasize aspects disregarded or only lightly treated in standard economics. Examples are that individuals always compare themselves to others, in particular when income and employment are concerned. They adapt or get used to many circumstances in their lives, such as income changes. This is the so-called Easterlin Paradox, which suggests that increases in real per capita income do not translate into corresponding increases in individual well-being (EASTERLin, 2001, 2004). Interestingly enough, this is not true for all changes. Thus, for example, unemployed males do not adapt to their fate while unemployed women do (Clark et al., 2006). Happiness theory also directs our attention to the importance of social relationships in the family and among friends and acquaintances (e.g. BRUNI and PORTA, 2005) and to procedural aspects such as the importance of the right to participate in politics (FreY and STUTZER, 2000a; see also Stadelmann-Steffen and Vatter, 2011).

While happiness research has provided us with a considerable number of new insights, it is only at its beginning. It is an excellent field for young researchers who want to engage in a fruitful and important area. One of the open issues is that empirically testable theories are needed that explain to whom individuals

2 For instance, income is an important determinant of individual happiness, but happy people tend to have a higher income. Similarly, being married contributes to happiness, while happy people are more likely to find a partner and to be married. See e.g. Frey and Stutzer (2006). 
compare themselves. It does not suffice to point to the importance of reference groups. Rather, reference groups are endogenous and it needs to be explained in what way they are chosen or imposed. Similarly, the speed and extent of adaptation to new circumstances need explanation.

A second area in which happiness research evolves concerns the measurement of the various types of individual well-being, e.g. short-run affect and long-run life satisfaction. There exists a considerable number of measurement approaches. While representative surveys dominate there is also the Day Reconstruction Method, the U-Index (measuring the share of time an individual feels unhappy), brain scanning or even blood pressure (see e.g. De Pricker, 2010, pp. 591-592; Oswald and Powdthavee, 2008). More fundamentally, the limitation of the measurement of happiness to pleasure and satisfaction, as initiated by BENTHAM (1789) and promoted e.g. by LAYARD $(1980,2005)$, should be reconsidered. The Benthamite concept seems to be rejected in modern philosophy (see e.g. McMAhon, 2006; Nussbaum, 2008) in favour of Plato's and Aristotle's concept of eudaimonia, i.e. the study of a fruitful human life.

Happiness research has concentrated on particular aspects while others have been neglected. Presently, studies (e.g. De Neve et al., 2011) attempt to capture the effect of human genes on individual well-being, which psychologists take to be substantial ${ }^{3}$ but which has so far been beyond the province of economics. Another neglected aspect is unhappiness during wars and other military conflicts. This is a challenging field because, against one's intuitions and hopes, there is no convincing empirical evidence that people in general are unhappier during war than in peacetime $e^{4}$.

The great success of happiness research has induced politicians to propose that "happiness should be maximized". This has been done e.g. by the French President $^{5}$ and by the British Prime Minister. Even the leaders of the People's Republic of China have adopted this stance. Much earlier, the Kingdom of Bhutan had decided to substitute the maximization of Gross National Product by the maximization of Gross National Happiness (UrA and Galay, 2004). Most recently, international organizations such as the OECD and the European Union have joined in.

This policy movement is supported by a large group of happiness scholars such as psychologists Seligman and Diener or economists Helliwell and Layard (see,

3 E.g. Lyubomirsky (2007) attributes between 40 and 60 percent of the variance of happiness between persons to inherited genetic factors.

4 The available evidence is collected in FrEY (2011a).

5 In the so-called Sarkozy report under the guidance of Stiglitz, Sen and Fitoussi (2009). 
more fully, De Pricker, 2010, pp. 588-590; also Sugden and Teng, 2008). "Maximizing happiness" can be taken to fulfil an old dream of technocratically orientated economists: for them, time has come to empirically fill Tinbergen's (1956) and Theil's (1964) concept of quantitative economic policy by maximizing a social welfare function.

This paper wants to inquire what kind of happiness policy should be pursued. I do not want to discuss the rather obvious point that GNP or GDP are not appropriate indicators for individual well-being. This has been discussed at length and is well established (e.g. René Frey, 2002, Fleurbaey, 2009, Stiglitz, Sen and Fitoussi, 2009). Nor do I want to discuss the many attempts to extend national product measures in various directions such as the Human Development Indicator composed of per capita income, longevity and level of education (UNDP, 1999, SEN, 1999). I will not discuss the broad counterarguments against "Happiness Maximization Policy" as this has been done elsewhere ${ }^{6}$. It must suffice to point out that such a policy avenue is in the tradition of a "benevolent dictator" approach. It disregards the incentives in the political process and assumes that politicians and public officials always pursue the "welfare of society" (whatever that be). This approach also disregards that individuals may value goals in their lives other than happiness, such as solidarity, justice, equality, freedom or religious ends.

This paper focuses on a little discussed aspect of government policy, namely that governments are not benevolent and that they make a strong effort to manipulate the official indicators of public policy. This will be called "Manipulation Principle". It is argued that this applies in particular to happiness policy. Section II argues that governments and other decision makers will manipulate all politically important targets as well as their respective indicators. While this Principle is of particular relevance for happiness policy, it also applies to many other policy areas. It results in government policies systematically deviating from the wishes of the citizens, therewith reducing aggregate happiness. Section III inquires what can be done to restrict and counterbalance the Manipulation Principle. It is proposed that the constitutional approach to policy allows citizens - informed by the results of happiness research - to choose for themselves how they want to become happy. Governments are given an enabling role only. Section IV concludes.

6 See De Prycker (2010); the author's own contributions are included in Frey and Stutzer (2000b, 2009, 2010, 2011b). 


\section{The Manipulation Principle}

\section{A. Incentives to Manipulate the Happiness Index}

Politicians in power have an incentive to manipulate the indicators for important policy targets. This Manipulation Principle applies to all governments, be they democratic, authoritarian or dictatorial. They all depend at least to some extent on the support of their population. In particular, if a government itself declares a goal to be the central one, it will make an effort to reach it, and be it by distorting the statistics that reflect that target. Therefore, a government declaring that "happiness" is the most important policy goal has a strong incentive to manipulate it in its favour and to make it look better than it is in reality. Such distortion of an indicator often carries less cost than an actual improvement of the target. Moreover, the indicator loses the information content it had been designed for. In the case of the happiness indicator, it does not reflect the well-being of individuals but provides a distorted picture of reality ${ }^{7}$.

The Manipulation Principle makes a simple but important point which has been little considered in the social sciences including economics ${ }^{8}$. It can be attributed to the sociologist CAmpbell (1976). In economics, Goodhart's Law (1975) and the Lucas Critique (1976) make a similar point. As soon as the quantity of money is made an official policy goal, it loses its usefulness as a policy. When a variable is a target of policy, the structure of the economic system changes. A more fundamental reference is to social choice theory where GibBaRd (1973) and Satterthwaite (1975) have proved that all democratic preference aggregation methods are open to manipulation.

Governments officially declaring happiness as their major policy goal have a strong incentive to make it look better than it is in actual fact. In a democracy, the voters evaluate government performance according to that indicator at election time (at least as long as they find it trustworthy). In authoritarian and dictatorial polities the rulers also have a strong interest to influence well-being indicators in their favour in order to prevent uprisings threatening their power.

7 With respect to the information content, see the discussion on the "performance paradox" (Meyer and Gupta, 1994; Meyer, 2005) discussed and extended in Osterloh (2010).

8 For instance, the extensive report on "The Politics of Governance Ratings" (ARNDT and OMAN, 2008) does not mention the incentives and possibilities for governments to manipulate ratings to their benefit. 


\section{B. Possibilities to Manipulate the Happiness Indicator}

A happiness indicator is well suited for manipulation because it is based on subjective evaluations rather than on (at least in principle) objective magnitudes such as quantities and prices. Subjective magnitudes are easier to manipulate. These are some possibilities for the politicians in power to make the happiness indicator look better than it actually is:

- The persons responding to a happiness survey may be influenced by propaganda or by threats in case they do not state that they are happy. This is a procedure that has been used to improve election outcomes but can and will also be used to jack up happiness figures.

- A well-known possibility to influence the results of (seemingly representative) surveys relates to the treatment of non-respondents. The happiness indicator can be raised by making an effort to trace initial non-respondents thought to have high happiness scores, and to neglect initial non-respondents thought to have below average happiness scores.

- The choice of respondents can be changed in yet other ways so as to produce an overrepresentation of individuals with above average happiness. Thus, mentally disturbed persons, the incarcerated and immigrants who tend to indicate lower levels of well-being than others can be excluded from the survey. Conversely, persons indicating above average happiness can be included, such as children or individuals voluntarily staying in the country as short run guests. It may be noted that such exclusion or inclusion can well be justified, thus immunizing the government from critique.

- Outliers indicating particularly extreme forms of unhappiness can be excluded arguing that they are "obviously untrue". In contrast, individuals indicating extremely high happiness are counted. Such manipulations are difficult to detect for observers not directly involved in the construction of a happiness indicator.

- "Special" circumstances beyond the control of government can be adduced in order to exclude the below average happiness scores declared by individuals who have suffered for example from natural disasters, terrorist attacks and foreign influences such as wars in other countries or damaging economic influences.

- The most extreme form of manipulation occurs when the government makes the survey responses up, which is similar to cooked election results. While there are some possibilities to detect the latter, it is more difficult to do so for happiness surveys based on subjective and often undocumented responses. 
If all these possibilities to manipulate the official happiness indicator do not work, or work insufficiently, the politicians in power have the possibility to introduce an altogether new indicator of well-being, thus producing more favourable happiness scores. They can claim, often to some extent correctly, that the former indicator was faulty and that the new one is better able to capture "true" happiness.

\section{Evidence on Manipulation}

It may appear that these possibilities to manipulate a happiness indicator in favour of the government are overemphasized and that, in reality, governments will not resort to these measures to raise the well-being indicators in their favour. However, there is strong empirical evidence that governments use many, if not all, of these tricks to influence specific economic indicators ${ }^{9}$ (ForTe, 2001; KoEN and VAn Den Noord, 2005; von Hagen and Wolff, 2006). For example, excluding those persons who are jobless but still engage in programmes for the unemployed, lowers the official unemployment rates. In many countries people who do not actively seek employment - mostly because they are discouraged to do so - are excluded from the pool of unemployed (see e.g. GregG, 1994; Yorgos, 1999; Webster, 2002). The level and growth rate of GNP are "cooked up" by including part or all of the shadow economy. The introduction of the Euro and later the Euro-crisis have induced many governments to falsify the size of the public debt (Dafflon and Rossi 1999; Milesi-Ferretti, 2005). Thus, for example, the government of Greece established public debt compared to GDP to be $115 \%$ at the end of 2009 , thereafter $127 \%$, and at the end of $2010145 \%$ (see, more generally, BARALEXIs, 2004). Argentina's government recently declared its official inflation rate to be $10 \%$ while an independent source determines it to be no less than 25\% (The Economist, 23 April 2011, pp. 75, 48, respectively). It should be noted that, if governments engage in manipulating individual economic indicators relevant in the political process, they have an even larger incentive to manipulate the aggregate well-being indicator once it has become the central and official goal of policy.

9 Economic indicators are subject to considerable errors even before any effort to manipulate them was made, as pointed out long ago by Morgenstern (1970), and documented for the case of the Human Development Index by Wolff et al. (2011). 


\section{Generalizing the Manipulation Principle}

Indicators of important targets are not only manipulated by governments but also by other decision-makers (such as interest groups) or the individuals affected. These are some cases in which the manipulation of indicators, sometimes called "creative accounting", plays a large role:

- Pay for performance. When the wage of employees depends on an indicator of performance, the employees have a strong incentive to manipulate it in their favour. The managers of a firm have excellent possibilities to do so as evidenced by the bookkeeping scandals at Enron, Worldcom and other large firms. The wage explosion among managers can at least partly be attributed to the fact that profits and other performance indicators can be, and have been, "cooked"10.

- Financial ratings. The financial system depends strongly on how particular government and private bond issues are rated by specialized private agencies. A downgrading in the credit ranking by one of the three big agencies (Moody's, Standard and Poor's or Fitch), has large financial consequences. Due to the increased risk of default heralded, the borrower has to pay higher rates of interest. It has been argued that the rating agencies are partly responsible for the recent financial and economic crisis because they respond to the pressure of the bond issuers and rate them more favourably than they should. More recently, the rating agencies have been accused of judging the default risk of government bonds by Greece, Portugal and other countries too unfavourably. As a reaction, politicians in and of the European Union (e.g. German Finance Minister Schäuble and EU-Commission President Barroso) threatened to take action against these rating agencies by "breaking their oligopolistic power" (Financial Times Deutschland, 7 July 2011, p. 23). This is another case in which governments seek to manipulate politically relevant indicators.

- Schooling. There is strong evidence (e.g. JАСОВ and LevitT, 2003) that schools whose success depends on fulfilling particular educational targets set by the money-giving institution not only teach to the test but also induce weak students not to attend school when the test is administered; another means being to exclude weak students altogether from their school.

- Academia. When the ranking of a university, a department, an institute or an individual scholar depends on the number of publications and citations, there

10 See, extensively and with many references, Osterloh (2010) or Frey and Osterloh (2010). 
are tremendous incentives to manipulate these rankings (they are extensively discussed in Osterloh and Frey, 2010). Many universities have one or even several employees charged with managing, i.e. manipulating, the rankings.

\section{E. Mitigating Manipulation}

Various institutions and actors can act to reduce the incentives and possibilities to influence official indicators of policy targets. I focus on the case of manipulation by governments:

\section{Independent statistical office}

The task to construct a policy indicator can be given to an institution independent of the government. This follows the example of two important actors in rule-based democracies, independent courts and an independent Central Bank. Another possibility is to delegate the task to international organizations such as the OECD, or to one of the UN institutions such as the World Bank, IMF or UNESCO. While they remain subject to the influence of powerful members, they are still more independent from particular governments than purely national agencies.

In the case of well-being, a country's central statistical office could be given an independent status to perform the task of constructing the aggregate happiness indicator. If this isolates it from government pressure, the Manipulation Principle would be checked. However, experience shows that in most countries of the world not even the Central Bank is independent, although it is "only" concerned with one particular policy sphere; its independence is a far less important restriction to government action. It follows that the central statistical office is most unlikely to be immune to government pressure.

\section{Academic critique}

The intellectual community - provided it is not subservient to government can to some extent check the Manipulation Principle. The scholars can criticize the government when it influences the happiness indicator in its favour and can therewith avert the citizens when the government tries to achieve the happiness goal by manipulation instead of by content. The freedom to criticize the government is better achieved when there are both publicly and privately funded universities in competition with each other. However, the necessary conditions obtain in few countries only. 


\section{Press and television}

Journalists may reveal manipulations of official indicators provided they can act independently and have an incentive to do so. A crucial requirement is intensive competition in this sector and absence of government interference.

\section{Digital social media}

The internet provides various platforms such as Wikileaks, Facebook, Twitter, or Google, potentially able to reveal when governments manipulate happiness indicators (e.g. Sunstein, 2006). Even if such open crowdsourcing detects instances of manipulation, the government is only threatened if the social media are able to make a scandal out of it. Otherwise, the rather technical aspects of the manipulations discussed above do not have much if any political effect. Social media lack the institutional basis for a prolonged campaign against such government action (Morozov, 2010; Frey, 2011b).

The discussion suggests that the Manipulation Principle is difficult to mitigate or to dispense with by either an independent institution providing the happiness indicator or by academic critique. The next section therefore proposes a more radical approach to develop a happiness policy in the interest of the citizens.

\section{Happiness Policy and Manipulation}

\section{A. Constitutional Approach}

A happiness maximization policy by the government is based on the technocratic notion that politicians and public officials are assumed to be omniscient benevolent dictators with no interests of their own. This approach is top down; it constitutes a fundamental misconception of a democratic process in which the preferences of the individuals in society are to count and in which the citizens and politicians are engaged in a continuous discourse ${ }^{11}$.

A totally different view of the political system is needed. The constitutional approach to political economy (BuCHanan and Tullock, 1962; Brennan and Buchanan, 1985; Mueller, 1996) starts with the individual as citizen and voter. He or she chooses political rules producing the best possible outcome in the

11 The latter is highlighted in the theory of deliberative or discursive democracy (e.g. DryzeK, 1990; Habermas, 1996; Sunstein, 2006). 
future. The future is known only to a small extent. In particular, nobody knows whether he or she, and the descendants, will in the future be rich or poor, be well educated or ignorant, have high or low capacities, be in good or bad health, live in the city or countryside etc. As a consequence, each citizen has to take decisions about the future behind the veil of ignorance (RAw LS, 1971). He or she therefore is induced to consider all possible future outcomes and will choose a constitution catering for all contingencies. While many trade-offs have to be considered, it is unlikely that voters choose e.g. a constitution caring only for the rich and successful while disregarding all the less fortunate persons because they reckon that they, or their descendants, may be among them in the unknown future. Rather, they choose rules allowing them to live under reasonable conditions if they happen to be among the persons with a less fortunate future.

\section{B. Application to Happiness Policy}

Behind the veil of ignorance, citizens will not allow the politicians and bureaucrats to maximize the happiness indicators as a policy goal. They are aware of the Manipulation Principle and will take into account that the government will not pursue their true happiness but rather an indicator distorted in the government's favour. Moreover, they know that there exists much heterogeneity with respect to what raises individual happiness. It can therefore be expected that citizens allow the government only to set the preconditions allowing them to reach their particular form of happiness.

In constitutional choice, the citizens will take into account the insights from happiness research. They will, for instance, acknowledge that an economic policy supporting full employment is of great importance to reach happiness. They will promote a good education for as many people as possible as they are aware that knowing more will allow them to reach higher levels of happiness. Most importantly, citizens will want to have extensive democratic participation rights and decentralized decision mechanisms since they know that these rules will allow them to raise their happiness.

In contrast to the happiness maximization approach, these insights serve as inputs into the political process and are not imposed by technocratic governments and bureaucracies. The latter are subservient to the citizens, not the other way round. Viewed in this way, the results of happiness research lose their technocratic inclination and become part of a well-designed political process. 


\section{Are Citizens Able to Choose Their Own Path to Happiness?}

The question arises whether voters are able to decide in a reasonable way about the constitutional rules governing their own well-being. In standard economics it is taken for granted that this is the case. Some results of happiness research put this assumption into question. It has been shown (e.g. Frey and Stutzer, 2008) that individuals find it difficult to evaluate to which extent future activities and goods will raise their happiness. A concrete case is commuting between the place of work and that of living. The longer the commute takes, the less satisfied the respective persons are with their lives, even taking into account the possible higher income attained or the lower housing rents. It should be noted that this is not an observation from outside the persons concerned. Rather, the result has been deduced on the basis of the persons' own evaluations. More generally, people tend to overestimate the future life satisfaction provided by material goods such as owning a flashy new car or a larger apartment. They only partly take into account that the happiness provided by such additional material goods is only temporary, i.e. that a process of adaptation will set in. In contrast, people tend to underestimate the satisfaction they get from future personal relationships, for instance by seeing friends and relatives more frequently. Another reason why individuals find it difficult to increase their own happiness is weakness of will, preventing them to sufficiently care for their future in their own interest.

A solution recently proposed to overcome the self-control problem is "nudging" by "soft paternalism" (Thaler and Sunstein, 2008; Glaeser, 2005): the alternatives available should be presented such that the individuals are induced to choose what is best for them. An example is the old age pension which individuals are reluctant to take because they tend to discount the future too strongly according to their own evaluation. Therefore, the softly paternalist government should present the choice such that people take the old age pension if they do not explicitly reject it. Another example is whether people can opt in, or opt out, of organ donation. It is known that more organs will be available when the issue is presented to people as an opt out choice. The problem with this approach is that it is implicitly assumed that the paternalistic government is benevolent. However, one could imagine a government nudging people into situations advantageous for the politicians in power but detrimental for the citizens.

The constitutional approach offers a better solution. Based on the results of happiness research, the citizens are informed that, under specific conditions, they are unable to choose according to their own best interest. They will be ready to introduce institutional devices helping them to overcome the respective deficient 
choices. They do not necessarily give governments the power to nudge them but may wish to be able to establish rules that help them overcome their deficiencies. Effective instruments are improved information and education, as well as an open discussion about the properties of the alternatives available.

Looking at the issues from the constitutional perspective makes clear that giving governments the power to pursue a happiness maximizing policy is ill conceived and even dangerous. The government in charge may well be, or become over time, authoritarian or even dictatorial. In that case, the Manipulation Principle will lead to political decisions that are disadvantageous for the citizens. An example is the government during the period of "terreure" in the French Revolution when - in the name of the "salut public" - many people with different opinions were put to death. It is also related to ideas such as OrwelL's (1949) "Ministry of Love" in his book Nineteen Eighty-Four. Today's dictatorships will act in a similar way.

\section{Concluding Remarks}

Happiness research has significantly extended our knowledge about what factors determine individual well-being. One of the unfortunate consequences of the success of happiness research has been the conclusion that governments should now engage in maximizing happiness. A happiness maximization policy by the government is based on the technocratic notion of politicians and public officials as omniscient benevolent dictators with no interests of their own.

A totally different view of the political system is needed. The constitutional approach to political economy starts with individuals as citizens and voters who choose a political system producing the best possible outcome in the future. Behind the veil of ignorance, citizens are aware of the Manipulation Principle: they take into account that the government will not pursue their true happiness but rather an indicator distorted in the government's favour. It can therefore be expected that the citizens allow the government only to set the preconditions allowing them to reach their particular form of happiness.

In that constitutional choice, the citizens will make decisions that are in line with the insights from happiness research. Most importantly, citizens will want to have extensive democratic participation rights and decentralized decision mechanisms, as they are aware that these rules will allow them to raise the kind of happiness they desire. 


\section{References}

Arndt, Christine, and Charles Oman (2008), "The Politics of Governance Ratings", International Public Management, 11, pp. 275-297.

Baralexis, Spyros (2004), "Creative Accounting in Small Advancing Countries: The Greek Case”, Managerial Auditing Journal, 19, pp. 440-461.

Barrotta, Pierluigi (2008), "Why Economists Should Be Unhappy with the Economics of Happiness", Economics and Philosophy, 24, pp. 145-165.

Bentham, Jeremy (1789) [1996], An Introduction to the Principles of Morals and Legislation, Clarendon.

Bok, Derex (2011), The Politics of Happiness: What Government Can Learn from the New Research on Well-Being, Princeton University Press.

Brennan, Geoffrey, and James Buchanan (1985), The Reason of Rules: Constitutional Political Economy, Cambridge University Press.

Bruni, Luigino (2006), Civil Happiness: Economics and Human Flourishing in Historical Perspective, Routledge.

Bruni, Luigino, and Pier Luigi Porta (eds) (2005), Economics and Happiness: Framing the Analysis, Oxford University Press.

Buchanan, James M., and Gordon Tullock (1962), The Calculus of Consent, Ann Arbor: University of Michigan Press.

Campbell, Donald T. (1976), "Assessing the Impact of Planned Social Change", occasional paper no. 8, Social Research and Public Policies, Dartmouth College, The Public Affairs Center.

Clark, Andrew E., Ed Diener, Yannis Georgellis and Richard E. Lucas (2006), "Lags and Leads in Life Satisfaction: A Test of the Baseline Hypothesis", Working paper, CNRS and DELTA-Fédération Jourdan.

Dafflon, Bernard, and Sergio Rossi (1999), "Public Accounting Fudges towards EMU: A First Empirical Survey and some Public Choice Considerations", Public Choice, 101(1-2), pp. 59-84.

De Neve, Jan-Emmanuel, Nicholas A. Christakis, James H. Fowler and Bruno S. Frey (2011), "Genes, Economics and Happiness”, CREMA Working Paper Series 2010-01, CESifo Working Paper Series 2946.

De Prycker, Valérie (2010), "Happiness on the Political Agenda? PROS and CONS”, Journal of Happiness Studies, 11, pp. 585-603.

Di Tella, Rafael, and Robert MacCulloch (2006), "Some Uses of Happiness Data in Economics", Journal of Economic Perspectives, 20, pp. 25-46.

Dolan, Paul, Tessa Peasgood and Mathew White (2008), "Do We Really Know What Makes Us Happy? A Review of the Economic Literature on 
the Factors Associated with Subjective Well-Being", Journal of Economic Psychology, 29, pp. 94-122.

Dryzer, John (1990), Discursive Democracy: Politics, Policy and Political Science, Cambridge University Press.

Dutt, Amitava K., and Benjamin Radcliff (eds) (2009), Happiness, Economics and Politics, Cheltenham, UK and Northampton, USA: Elgar.

Easterlin, Richard A. (1974), "Does Economic Growth Improve the Human Lot? Some Empirical Evidence", in Nations and Households in Economic Growth: Essays in Honour of Moses Abramowitz, Paul A. David and Melvin W. Reder (eds), New York: Academic Press.

Easterlin, Richard A. (2001), "Income and Happiness: Towards a Unified Theory", Economic Journal, Royal Economic Society, 111(473), pp. 465-84.

Easterlin, Richard A. (2002), Happiness in Economics, Cheltenham UK and Northampton, MA, USA: Elgar.

Easterlin, Richard A. (2004), "Explaining Happiness", Proceedings of the National Academy of Sciences Nations and Households in Economic Growth: Essays in Honour of Moses Abramowitz, 100, pp. 1176-1183.

Easterlin, Richard A. (2010), Happiness, Growth, and the Life Cycle, New York: Oxford University Press.

Eid, Michael, and Randy J. Larsen (eds) (2008), The Science of Subjective WellBeing, New York and London: Guilford Press.

Fleurbaey, M. (2009), "Beyond GDP: The Quest for a Measure of Social Welfare", Journal of Economic Literature 47, pp. 1029-1075.

Forte, Francesco (2001), "The Maastricht 'Excessive Deficit' Rules and Creative Accounting", in: Rules and Reason: Perspectives on Constitutional Political Economy, Mudambi, Ram, Pietro Navarra and Giuseppe Sobbrio (eds), Cambridge: Cambridge University Press.

Frey, Bruno S. (2008), Happiness: A Revolution in Economics, Cambridge, MA and London, England: The MIT Press.

Frey, Bruno S. (2011a), "Peace, War and Happiness. Bruder Klaus as Well-Being Facilitator", International Journal of Well-being, in press.

Frey, Bruno S. (2011b), "Tullock Challenges: Happiness, Revolutions and Democracy", Public Choice, in press.

Frey, Bruno S., and Alois Stutzer (2000a), "Happiness, Economy and Institutions", The Economic Journal, 110, pp.918-938.

Frey, Bruno S., and Alois Stutzer (2000b), "Maximizing Happiness?", German Economic Review 1, pp. 146-167.

Frey, Bruno S., and Alois Stutzer (2002a), Happiness and Economics, Princeton and Oxford: Princeton University Press. 
Frey, Bruno S., and Alois Stutzer (2002b), "What Can Economists Learn from Happiness Research?”, Journal of Economic Literature, 40(2), pp. 402-435.

Frey, Bruno S., and Alois Stutzer (2004), "Reported Subjective Well-Being: A Challenge for Economic Theory and Economic Policy", Schmollers Jahrbuch, 124, pp. 191-231.

Frey, Bruno S., and Alois Stutzer (2005), "Happiness Research: State and Prospects”, Review of Social Economy, 62, pp. 207-228.

Frey, Bruno S., and Alois Stutzer (2006), "Does Marriage Make People Happy, or Do Happy People Get Married?", The Journal of Socio-Economics, 35, pp. 326-347.

Frey, Bruno S., and Alois Stutzer (2008), "Economic Consequences of Mispredicting Utility”, CREMA Working Paper Series 2005-04.

Frey, Bruno S., and Alois Stutzer (2009), "Should Happiness Be Maximized?", in Happiness, Economics and Politics, Amitava K. Dutt and Benjamin Radcliff (eds), pp.97-126, Cheltenham, UK, and Northampton, USA: Elgar.

Frey, Bruno S., and Alois Stutzer (2010), "Happiness and Public Choice", Public Choice, 144, pp. 557-573.

Frey, Bruno S., and Claudia Frey Marti (2011), Glück - Die Sicht der Ökonomie, Zurich and Chur: Rüegger.

Frey, Bruno S., and Margit Osterloh (2010), "Evaluations: Hidden Costs, Questionable Benefits and Superior Alternatives", in Professional pride - a powerful force, T. Jansen, G. van den Brink, J. Kole, The Hague, pp. 175-196.

Frey, René (2002), Wirtschaft, Staat und Wohlfahrt. Eine Einführung in die Volkswirtschaftslehre am Beispiel der Schweiz, Basel and Frankfurt a. M.: Helbing und Lichtenhahn.

Gibbard, Allan (1973), "Manipulation of Voting Schemes: A General Result", Econometrica, 41(4), pp. 587-601.

Gilbert, Daniel (2006), Stumbling on Happiness, New York: Knopf.

Glaeser, Edward L. (2005), "Paternalism and Psychology", NBER Working Papers 11789.

Goodhart, Charles (1975), "Monetary Relationships: A New Form of Threadneedle street", Papers in Monetary Economics, 1, Reserve Bank of Australia.

Gregg, Paul (1994), "Out of the Count: A Social Scientist's Analysis of the Unemployment Statistics in the UK", Journal of the Royal Statistical Society, Series A 157, pp. 253-250.

Habermas, Jürgen (1996), Between Facts and Norms - Contributions to a Discourse Theory of Law and Democracy, London: Polity.

Haybron, Daniel M. (2008), The Pursuit of Unhappiness. The Elusive Psychology of Well-Being, Oxford: Oxford University Press. 
Hicks, John, and Roy Allen (1934), "A Reconsideration of the Theory of Value", Economica, 1, pp. 52-75.

Jacob, Brian A., and Steven D. Levitt (2003), "Rotten Apples: An Investigation of the Prevalence and Predictions of Teacher Cheating", Quarterly Journal of Economics, 118, pp. 843-877.

Kahneman, Daniel, and Alan B. Krueger (2006), "Developments in the Measurement of Subjective Well-Being", Journal of Economic Perspectives 20, pp. 3-24.

Kahneman, Daniel, Ed Diener, and Norbert Schwarz (eds) (1999), WellBeing: The Foundations of Hedonic Psychology, New York: Russell Sage Foundation.

Koen, Vincent, and Paul Joseph Van den Noord (2005), "Fiscal Gimmickry in Europe: One-off Measures and Creative Accounting", OECD Economic Department Working Paper No 417.

Lane, Robert (2000), The Loss of Happiness in Market Economies, Yale University Press.

Layard, Richard (1980), "Human Satisfaction and Public Policy", Economic Journal, 90, pp. 737-750.

Layard, Richard (2005), Happiness: Lessons from a New Science, New York: Penguin Press.

Lucas, Robert E. (1976), "Econometric Policy Evaluation: A Critique", in Carnegie-Rochester Conference Series on Public Policy. The Phillips Curve and Labor Markets, Karl Brunner and Alan H. Meltzer (eds), pp. 19-46, New York: North Holland.

Lyubomirsky, Sonja (2007), The How of Happiness. A Scientific Approach to Getting the Life You Want, New York: Penguin Press.

McMahon, Darrin M. (2006), Happiness: A History, New York: Atlantic Monthly Press.

Meyer, Marshall W. (2005), "Can Performance Studies Create Actionable Knowledge If We Can't Measure the Performance of the Firm?", Journal of Management Inquiry, 14(3), pp. 287-291.

Meyer, Marshall W., and V. Gupta (1994), "The Performance Paradox", Research in Organisational Behaviour, 16, pp.309-369.

Milesi-Ferretti, Gian Maria (2004), "Good, Bad or Ugly? On the Effects of Fiscal Rules with Creative Accounting", Journal of Public Economics, 88, pp.377-394.

Morozov, Evgeny (2010), The Net Delusion. How Not to Liberate the World, London: Allen Lane. 
Morgenstern, Oscar (1970), On the Accuracy of Economic Observations, $2^{\text {nd }}$ ed., Princeton: Princeton University Press.

Mueller, Dennis (1996), Constitutional Democracy, Oxford University Press.

Nussbaum, Martha C. (2008), "Who is the Happy Warrior? Philosophy Poses Questions to Psychology", Journal of Legal Studies, 37(S2), pp. 81-113.

Orwell, George (1949), Nineteen Eighty-Four, Harmondsworth: Penguin, reprinted 1990.

Osterloh, Margit (2010), "Governance by Numbers. Does it Really Work in Research?”, Analyse und Kritik, 32, pp. 267-283.

Oswald, Andrew J., and Powdthavee, Nattavudh (2008), "Death, Happiness, and the Calculation of Compensatory Damages", Journal of Legal Studies, 37, pp. 217-252.

Rawls, John (1971), A Theory of Justice, Harvard University Press.

Robiins, Lionel (1932), An Essay on the Nature and Significance of Economic Science, Macmillan. Selections reprinted in The Philosophy of Economics: An Anthology, D. Hausman (ed.), Cambridge University Press.

Satterthwaite, Mark (1975), "Strategy-Proofness and Arrow's Conditions: Existence and Correspondence Theorems for Voting Procedures and Social Welfare Functions", Journal of Economic Theory, 10, pp. 187-217.

Sen, Amartya K. (1999), Development and Freedom, New York: Knopf.

Stadelmann-Steffen, Isabelle, and Adrian Vatter (2011), "Does Satisfaction with Democracy Really Increase Happiness? Direct Democracy and Individual Satisfaction in Switzerland", Political Behavior, published online 10 May 2011.

Stiglitz, Joseph E., Amartya Sen and Jean-Paul Fitoussi (2009), Report by the Commission on the Measurement of Economic Performance and Social Progress, http:/www.stiglitz-sen-fitoussi.fr.

Sugden, Robert, and Joshua Chen-Yuang Teng (2008), "Is Happiness a Matter for Governments? A Millian Perspective on Layard's 'new science", Mimeo, School of Economics, University of East Anglia.

Sunstein, Cass R. (2006), Infotopia - How Many Minds Produce Knowledge, Oxford: Oxford University Press.

Thaler, Richard H., and Cass R. Sunstein (2008), Nudge: Improving Decisions about Health, Wealth, and Happiness, New Haven, CT: Yale University Press.

Theil, Henry (1964), Optimal Decision Rules for Government and Industry, North-Holland.

Tinbergen, Jan (1956), Economic Policy: Principles and Design, New York: North-Holland. 
UNDP (1999), Human Development Report, New York: Oxford University Press.

Ura, Karma, and Karma Galay (eds) (2004), Gross National Happiness and Development, Centre for Bhutan Studies, Bhutan.

Veenhoven, Ruut (1989), Conditions of Happiness, Dordrecht and Boston: Kluwer Academic.

Von Hagen, Jürgen, and Guntram B. Wolff (2006), "What Do Deficits Tell Us about Debt? Empirical evidence on Creative Accounting with Fiscal Rules in the EU”, Discussion Papers 148, SFB/TR 15 Governance and the Efficiency of Economic Systems, Free University of Berlin, Humboldt University of Berlin, University of Bonn, University of Mannheim, University of Munich.

Vournas, Yorgos (1999), "Official Statistics and the Manipulation of Conceptual and Technical Instruments: Implications for Research on Social Security", Radical Statistics, 72.

Webster, David (2002), "Unemployment. How Official Statistics Distort Analysis and Policy and Why", Radical Statistics, 79/80.

Wolff, Hendrik, Howard Chong and Maximilian Auffhammer (2011), "Classification, Detection and Consequences of Data Error: Evidence from the Human Development Index", Economic Journal, 121, pp. 843-870.

\section{SUMMARY}

Happiness research has significantly extended our knowledge about the factors determining individual well-being. Several prominent scholars concluded that governments should engage in maximizing happiness. This approach is based on a technocratic notion that politicians are omniscient benevolent dictators.

In contrast, the constitutional approach considers individuals as citizens who, behind the veil of ignorance, choose political rules producing the best possible outcome. Citizens are aware of the Manipulation Principle stating that government tends to distort official happiness indicators in its favour. Citizens therefore demand extensive democratic participation rights allowing them to pursue the kind of happiness they desire. 